$5^{\mathrm{TH}}$ CARPE CONFERENCE

23-25 ${ }^{\text {th }}$ October 2019, Valencia (Spain)

http://dx.doi.org/10.4995/CARPE2019.2019.10206

\title{
Examination of sustainable and health-conscious lifestyle among the Hungarian population based on the results of three research studies
}

\author{
Kiss, V. ${ }^{1}$, Balsa-Budai, N. ${ }^{1}$, Soós, M. ${ }^{1}$, Szakály, Z. ${ }^{1}$ \\ ${ }^{1}$ Faculty of Economics and Business, Institute of Marketing and Commerce, University of \\ Debrecen, Hungary
}

\begin{abstract}
The implementation of sustainable development and the associated values in consumer behavior is becoming more and more emphasized as well as the increased attention to our health. In both value dimensions, consumer interest is constantly increasing, and the demand for healthy and sustainable products is growing. In our research, this trend was primarily investigated in the field of food consumption. The research was based on the segmentation theory of NMI's LOHAS (Lifestyle of Health and Sustainability).

The research consisted of three parts. First, in a nationally representative survey, we examined the commitment of Hungarian adult consumers to the aforementioned values $(N=1000)$, then high school students $(N=1000)$, and finally, university students $(N=298)$ were interviewed on the same topic. In each case, principal component analysis was used to isolate the individual value dimensions and then cluster analysis was used to identify the various segments. In all of the three studies, each group was significantly separated from each other by the values of health consciousness and sustainable development.
\end{abstract}

Based on our results, it can be concluded that the younger age group is more strongly committed to the tested values than the older generation. Consequequently, younger generations can be considered a potential consumer market for products and services representing sustainability and health awareness. We believe that further European research on this topic would be useful for both the researchers and the business sector.

Keywords: sustainability, health, consumer behavior, LOHAS 


\section{Introduction}

Creating an environment, in which the present and future generations can live and grow in peace and good environmental conditions is a priority for all societies (Kiss et al., 2016).

The challenge of implementing sustainable development at the practical level and taking action is to identify it as a global problem, so it is further away from our individual interests. Numerous studies report that consumers perceive this question as a responsibility of government bodies, companies and not their own (NMI, 2015, Kiss et al., 2018).

In the present study, we have collected research findings, models, and theories that are relevant to the examination of a group that seeks to act as consciously as possible when making consumer decisions, taking into account global issues and personal development. In recent years, there have been several groups identified as having a value dimension associated with one or another issue of sustainable development, namely groups that are environmentally conscious, ethical or ethnocentric. Below, we present the LOHAS (Lifestyle of Health and Sustainability) market segment and its attitudes based on international, Hungarian and our research. (Kiss et al., 2018).

\section{The Lifestyle of Health and Sustainability segment}

"LOHAS is an umbrella acronym that stands for Lifestyles Of Health And Sustainability. Both for people and the planet it refers to a wide range of industries, corporate activities and products/services that are designed to be environmentally conscious, sustainable, socially responsible, and/or healthier" (French \& Rogers, 2015, p. 1). The Natural Marketing Institute was the first to make this segment known worldwide and to do more research to gain a deeper understanding of this segment. Although Baker identified them before 1999, research on the subject started only after 2005. Already in the early years, the LOHAS Group emphasized personal values about "self and about the social and natural worlds". In addition, they are willing to pay extra for products, which could represent their commitment to these values (Emerich, 2011). The LOHAS Group actively defends its environment and makes its purchasing decisions that way. It takes into account the factors that are best for your own health and that of our planet. They are lifestyle oriented, keeping individual interests in mind. They represent the largest customer group in the green and socially responsible product market (NMI, 2008, Kiss et al., 2018).

Harding (2010) divided the LOHAS market into five segments (Figure 3), and added the importance of Social Justice. In his view, it is along with these values that the most profitable products and services for the LOHAS segment can be created and sold (Kiss et al., 2018. 


\section{Figure 3: LOHAS market}

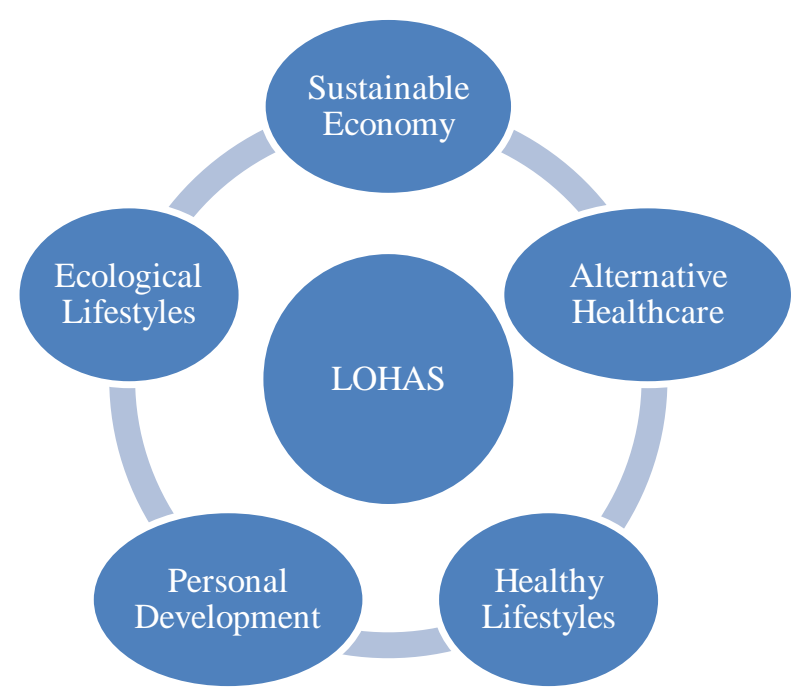

Source: Harding, 2010

However, because of hedonism and its seemingly contradictory values experts question whether the members of LOHAS lifestyle can really be considered the consumer group to achieve the most sustainable consumption. For this reason, we found it necessary to extend our research to another segment as well, which is also dedicated to sustainable consumption (Balsa-Budai - Szakály, 2018).

The segment of voluntary simplifiers, also known as Lifestyle Of Voluntary Simplifiers was identified in the 1930s in America (Gregg, 2003). The representatives of this lifestyle - as the acronym of their name implies - primarily strive to create a simple, sustainable lifestyle where they turn away from materialistic values and the pursuit of maximizing material wealth (Balsa-Budai - Szakály, 2018).

\section{Materials and methods}

The review of the literature highlighted which values best describe the LOHAS lifestyle. Based on the results of the content analysis of them, a list of statements was made containing 50 elements, 21 of which were analyzed later (Szakály et al, 2017).

For the examinations, two methods were used to make the dimensions of values, and create consumer segments. This study will show significant and eligible results only. 
The first examination is based on a nationally representative questionnaire. The survey was carried out in Hungary in 2014, involving 1000 people. Representativeness, regions and settlement types are provided by the quota sampling method (Szakály et al., 2017).

The aim of the second examination was to examine the conscious consumer and health behaviour on a sample representative of the sex and age of the population of Hungarian secondary school students $(\mathrm{n}=1001)$ (Kiss et al, 2016).

The third study focused on university students' opinions, it was based on a non-representative survey which involved 298 people. (Budai - Szakály, 2018).

\section{Results of our research studies}

Over the past five years, we have conducted four pieces of research on the LOHAS segment. Three of them will be introduced here. We examined the Hungarian adult population, Hungarian university students and Hungarian high school students.

\subsection{Findings on Hungarian adults}

Based on the results five value-based segments can be distinguished. These segments were the Young Trend Followers, the Ethical Tradionalists, the Young Environmentally Conscious People, the Uninvolved Elderly People and the Disappointed Pessismists. The biggest cluster was the Young Trend Followers and this group reflects the characteristics of the LOHAS consumer lifestyle to the greatest extent. However, this segment cannot be considered as a fully engaged consumer group by LOHAS values, so further segmentation of this group was needed. As a result of this the third subgroup of this further segmentation emphasizes ethical competence and most claims are identified by the LOHAS consumer group. This segment accounts for $8.7 \%$ of the Hungarian population. Further research is needed to determine similarities in value orientation with other Eastern European countries, where the social and cultural background is very similar to Hungary and to compare Hungary with western countries to discover differences in consumer attitudes (Szakály et al., 2017).

\subsection{Findings on university students}

In the examination of university students, with factor analysis six value dimensions were defined. They are as follows: the health conscious, the sustainable development, the social, the product-oriented, the traditionalist and the individualist. Based on the dimensions four segments were created by K-means cluster analysis. These were the Ambitious Trendfollowers, the Conscious Simplifiers, the Traditional Individualists, the Health Conscious people. In the case of the LOHAS consumer group, the Ambitious Trend Followers (the cluster size was $25.1 \%$ of the students asked) reflect the characteristics of the LOHAS consumers' lifestyle to the greatest extent. In the case of the LOVOS consumer 
group, the most dedicated cluster was the Conscious Simplifiers (the cluster size was $34.55 \%$ of the students asked). However, this segment does not entirely reflect all the values of the LOVOS consumers' lifestyle, so further research is necessary in the future (Balsa-Budai Szakály, 2018).

\subsection{Secondary school pupils' attitudes to health and sustainablity}

For the examination of the youngest group, the principal component analysis was used, which could discover five value dimension which was similar to the findings on adults. These were as follows: the trendy individualist, the health and environmentally conscious, the authentic patriot, the altruist ethical and the follower of firm ethical behavior. With them, we could determine four segments with K-means cluster analysis. The segments were named as Conscious trend avoiders (who could be similar to Conscious Simplifiers), Responsibility Avoiders, Passive first-year pupils and Conscious individualists (who can be identified as the LOHAS group).

\section{Discussion}

As discussed earlier, the implementation of sustainable development and the associated values in consumer behavior is becoming more and more important as well as our health. In both value dimensions, consumer interest is constantly increasing, and the demand for healthy and sustainable products is growing.

In our research, we have explored the Hungarian conscious segments, and this knowledge is useful for companies and the state. Further international research would provide an opportunity to discover and compare global and local needs and attitudes and to better understand the market opportunities of conscious lifestyles.

\section{References}

Balsa-Budai, N. \& Szakály, Z. (2018): A fenntartható értékrend vizsgálata debreceni egyetemisták körében (The investigation of sustainable values among the students of the University of Debrecen). Táplálkozásmarketing (The Hungarian Journal of Nutrition Marketing), 5(1), 3-20.

Kiss, V. A., Kiss, M., Popovics, P. \& Szakaly, Z. (2018): Examination of Lifestyle of Health and Sustainability market groups with particular focus on Hungary. In: Gazdecki, M. Gorynska-Goldmann, E. (eds.) Relationships on Food Markets - Consumers' perspective. Poznan University of Life Sciences. 